
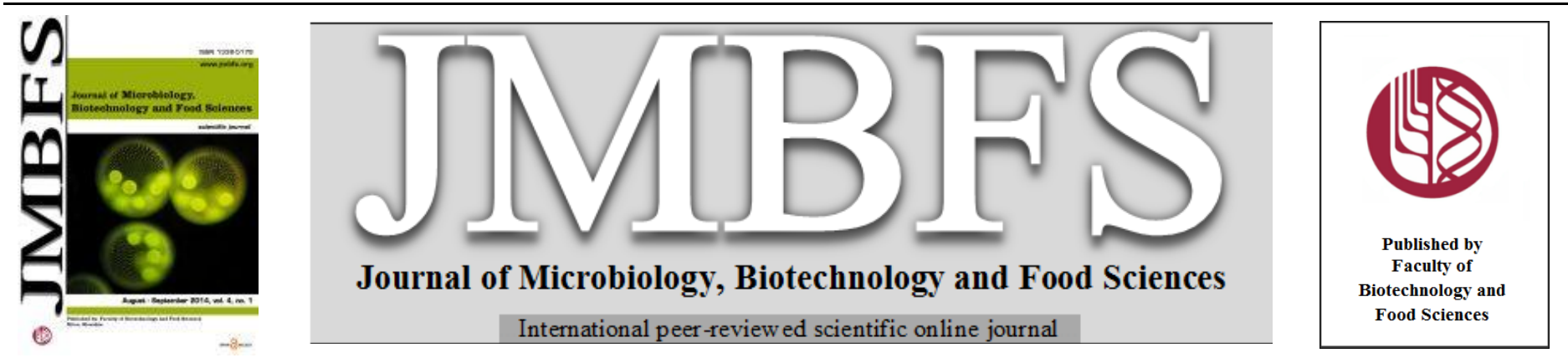

\title{
PARTIAL PURIFICATION OF MILK-CLOTTING ENZYME FROM THE SEEDS OF MORINGA OLEIFERA
}

\author{
Amna E. Tajalsir ${ }^{1}$, Ali S. A. Ebraheem ${ }^{1}$, Abdelmoez M. Abdallah ${ }^{l}$, Fatima J. Khider ${ }^{1}$, Mohamed O. Elsamani ${ }^{2}$, and Isam A. \\ Mohamed Ahmed ${ }^{1,3} *$
}

\author{
$\operatorname{Address}(e s)$ : \\ ${ }^{1}$ Department of Food Science and Technology, Faculty of Agriculture, University of Khartoum, Shambat 13314, Khartoum North, Sudan. \\ ${ }^{2}$ Department of Food Science and Technology, Faculty of Agriculture, Omdurman Islamic University, Omdurman, Sudan. \\ ${ }^{3}$ Arid Land Research Center, Tottori University, Tottori 680-0001, Japan.
}

*Corresponding author: isamnawa@yahoo.com

doi: 10.15414/jmbfs.2014.4.1.58-62

ARTICLE INFO

Received 17. 6. 2014

Revised 3. 7. 2014

Accepted 21. 7. 2014

Published 1. 8. 2014

Regular article

open $\partial_{\text {ACCESS }}$

\section{ABSTRACT}

The aim of the present study was to search for milk clotting substitute from different parts (flowers, seeds, stem, leaves, ripe and unripe fruits) of Moringa oleifera. The samples were blended and extracted using different types of extracting solutions. The most reliable, quick and efficient enzyme extracting solution was found to be $5 \% \mathrm{NaCl}$ in $100 \mathrm{mM}$ sodium acetate buffer, $\mathrm{pH}$ 5.0, which was used throughout the study. The milk clotting activity was only observed in the seeds extract while the other parts were either deficient or has very low milk clotting activity. Thus, the moringa seeds were used as source of milk clotting enzyme. The extracted proteins were fractionated with ammonium sulfate at concentration of 20,30, 40, 50 and $60 \%$. Highest milk clotting activity was observed in the 20 $\%$ fraction. This fraction was assumed to contain the clotting enzymes and characterized for its heating stability $\left(30-90^{\circ} \mathrm{C}\right)$ and optimum temperature $\left(30-90^{\circ} \mathrm{C}\right)$. The results demonstrated that moringa seeds milk clotting enzyme is stable up to $50^{\circ} \mathrm{C}$ with an optimum milk clotting activity of $70^{\circ} \mathrm{C}$. The high ratio of milk-clotting to proteolytic activity of the partially purified enzyme indicates the potential of this enzyme as suitable rennet substitute in dairy industry. However, further study is needed to completely purify and characterize this promising milk clotting enzyme from moringa seeds.

\section{INTRODUCTION}

Cheese is the generic name for a group of fermented milk-based food products, with more than 1000 types, produced in a wide range of flavours and forms throughout the world that has played a key role in human nutrition for more than 8000 years (Fox \& McSweeney 2004). The main objective has always been and still is to convert milk, which is perishable, into a product with a longer shelf life whilst preserving its nutrients (Mohamed Ahmed et al., 2010). Milk coagulation is the basic step in the manufacture of most types of cheeses and calf rennet has been and still the most widely used milk-clotting enzyme preparation (Mohamed Ahmed et al., 2009a). However, the last decades have witnessed by the population explosion that lead to an increased demand for cheese production and consumption. Together with that the price of calf rennet's was greatly increased, along with a reduced supply of natural calf rennet (Mohamed Ahmed et al., 2010). In addition to that, the use of animal rennet is limited for religious reasons (e.g. Judaism and Islam), safety reasons (bovine spongiform encephalopathy), diet (vegetarianism), or being against genetically engineered foods (Roseiro et al., 2003). All these reasons have necessitated the search for new protease with high specific milk-clotting activity and low general proteolytic activity to be used as a rennet substitute. Accordingly, much research interest has been directed towards discovering a milk-clotting enzyme which would satisfactory replace calf rennet in cheese manufacture, and numerous enzyme preparations of animal, microbial, and plant origin have been studied (Jacob et al., 2011). Microbial rennets produced by genetically engineered bacteria have proven to be suitable substitutes for animal rennet, but increasing attention has been directed toward natural rennet extracted from plants such as Ananas comosus, Carica papaya, Calotropis porcera, Ficus carica, Calm viscera, Cynara cardunculus (Roseiro et al., 2003), Cynara scolymus (Sidrach et al., 2005), and Solanum dubium (Mohamed Ahmed et al., 2009 a, b) among others. Unfortunately, most of these plant rennets were found inappropriate because they possess high general proteolytic activity, which leads to the production of short peptides that are responsible defect in flavor and texture of cheese (Anusha et al., 2014). An exception to this general rule is represented by the aqueous extract of Cynara cardunculus flowers containing two aspartic acids-type proteases, named cardosin A and B (Verissimo et al., 1995), which has been used for years for the manufacture of sheep milk cheese in several areas of Portugal and Spain. However, the flowers of Cynara cardunculus are not used for the production of cow-milk cheeses as they tend to taste bitter because of the formation of several peptides identifiable in the digests of isolated bovine $\beta$ - and $\alpha$-casein (Macedo et al., 1996). Thus, the search for a rennet substitute from plant sources having high ration of milk clotting to general proteolytic activity is highly needed to overcome the above mentioned problems.

Moringa oleifera is native to the sub-Himalayan tracts of India, Pakistan, Bangladesh and Afghanistan and it is an important crop in India, Ethiopia, the Philippines and the Sudan. All parts of this rapidly-growing tree are edible and have long been consumed by the ancient Romans, Greeks and Egyptians (Fahey 2005). It is the most nutrient-rich plant yet discovered as it contains all the essential nutritional elements that are essential for livestock and human beings (Fahey 2005). Many parts of this miracle tree have been used in various applications such as food for overcoming malnutrion, feed for weight gain and milk production, medicine for the treatment and/or prevention of many diseases, and environment for water clarification (Fahey 2005). Despite the wide spread and huge uses of Moringa oleifera, it uses as a source of milk clotting enzymes is scarce. Only one report has recently been published indicating that the presences of caseinolytic and milk-clotting activities from flowers of Moringa oleifera (Pontual et al., 2012). This activity has only been detected after the precipitation of the protein with $60 \%$ ammonium sulfate (Pontual et al., 2012) indicating low concentration of such enzyme in the flowers. Nevertheless, extracts from other parts of this important tree have not been tested for their milk-clotting ability. Moreover, isolation and characterization of milk-clotting enzymes from any part of this tree has not yet been reported. Therefore, in the current study crude extracts from different parts of Moringa oleifera has been screened for their milkclotting activity using skimmed milk as substrate. Milk-clotting activity was only detected in the seeds extract of this tree. This enzyme was further partially purified by using ammonium sulfate precipitation techniques, and then milkclotting properties and temperature profile of the partially purified enzyme were evaluated. 


\section{MATERIAL AND METHODS}

\section{Material}

Moringa oleifera samples were supplied by engineer Salah Abdoun at Moringa Research and Development Group Farm, Khartoum North, (Al-Samrab). These samples include leaves, stems, flowers, unripe fruits, ripe fruits and seeds. All fresh samples were dried for two days at room temperature. Thereafter, samples were ground using house grinder and store in closed containers in the freezer at $20^{\circ} \mathrm{C}$ until use. All chemical used were of analytical grade.

\section{Enzyme extraction}

Different extracting buffers were tried for the extraction of milk-clotting enzyme from different parts of Moringa oleifera (flowers, seeds, stem, leaves, ripe and unripe fruits), which were distilled water, $5 \% \mathrm{NaCl}$ in distilled water, sodium acetate buffer ( $\mathrm{pH} 5.0)$, and $5 \% \mathrm{NaCl}$ in sodium acetate buffer ( $\mathrm{pH}$ 5.0). Moringa oleifera samples (5.0 $\mathrm{g}$ each) were finely ground by grinder and extracted with 50 $\mathrm{ml}$ of each extractant for $4 \mathrm{~h}$ with stirring. The extracts were filtrated through cheesecloth and centrifuged at $12,000 \times g$ for $20 \mathrm{~min}$. The supernatants were dialyzed overnight against $0.1 \mathrm{M}$ sodium acetate buffer, $\mathrm{pH}$ 5.0. Milk-clotting and protease activities in addition to protein concentration in each extract were determined.

\section{Ammonium sulfate fractionation}

Ammonium sulfate fractionation was carried out following the method described elsewhere (Mohamed Ahmed et al., 2009a). Solid ammonium sulfate was slowly added with stirring to the crude extract $(50 \mathrm{ml})$ preparations to $20 \%$ saturation. During the addition of solid ammonium sulfate, the $\mathrm{pH}$ of the enzyme solution was kept at $\mathrm{pH} 5.0$ by a drop wise addition of either $7 \% \mathrm{NH}_{4} \mathrm{OH}$ or 0.1 $\mathrm{M} \mathrm{H}_{2} \mathrm{SO}_{4}$, and the mixture was kept on ice for $30 \mathrm{~min}$. The precipitates were separated from the supernatant by centrifugation at $12,000 \times \mathrm{g}$ for $20 \mathrm{~min}$ at room temperature. Solid ammonium sulfate was further slowly added to the supernatant to $30 \%$ saturation and the solution was kept on ice for another $30 \mathrm{~min}$ before being centrifuged at $12,000 \times g$ for $20 \mathrm{~min}$ at $4^{\circ} \mathrm{C}$. This process was repeated for each concentration of ammonium sulfate until reach $60 \%$ saturation. The precipitates collected were dissolved in a small volume (about $10 \mathrm{ml}$ ) of 50 $\mathrm{mM}$ sodium acetate buffer, $\mathrm{pH} 5.0$, and then dialyzed overnight at $4{ }^{\circ} \mathrm{C}$ against the same buffer (1.0 liter) with several change of the dialysis buffer. The dialyzed solutions were further centrifuged to remove any solid particles, and their protein concentration, milk-clotting and proteolytic activities were measured. The most active fraction with high yield was pooled and used to characterize the enzyme.

\section{Determination of milk-clotting activity}

Milk-clotting activity was determined according to the methods described elsewhere (Arima et al., 1970). The substrate $(10 \%$ skimmed milk in $0.01 \mathrm{M}$ $\mathrm{CaCl}_{2}$ ) was prepared and the $\mathrm{pH}$ was adjusted to 6.5 . Then, ten millimeters of the substrate was pre-incubated for $5 \mathrm{~min}$ at $37^{\circ} \mathrm{C}$, and $1.0 \mathrm{ml}$ of enzyme extract was then added, and the curd formation was observed at $37^{\circ} \mathrm{C}$ while manually rotating the test tube from time to time. The end point was recorded when discrete particles were discernible. One milk-clotting unit is defined as the amount of enzyme that clots $10 \mathrm{~mL}$ of the substrate in $40 \mathrm{~min}$.

MCA $(\mathrm{U} / \mathrm{ml})=(2400 /$ clotting time $(\mathrm{sec})) \times$ Dilution factor

\section{Protease activity assay}

In this method (Sarath 1989), 1\% casein solution was prepared in $50 \mathrm{mM}$ potassium phosphate buffer, $\mathrm{pH} 6.5$. To start the assay, $0.5 \mathrm{ml}$ of temperatureequilibrated substrate was added to $0.1 \mathrm{ml}$ of the enzyme solution (in centrifugal tube) and mixed gently. The reaction mixture was incubated at $30^{\circ} \mathrm{C}$ for $30 \mathrm{~min}$, and then the reaction was terminated by the addition of $1.0 \mathrm{ml}$ of $5 \%$ trichloroacetic acid (TCA). The blank was prepared in the same way by adding TCA prior to the addition of the substrate. After standing for $30 \mathrm{~min}$ at room temperature, the reaction mixtures were centrifuged at $12,000 \times g$ for $20 \mathrm{~min}$ to separate the TCA-soluble products. The absorbance was read at $280 \mathrm{~nm}$ with reference to the blank. One unit of the enzyme activity was defined as the amount of the enzyme required to cause a unit increase in absorbance at $280 \mathrm{~nm}$ across a $1 \mathrm{~cm}$ path length, under the assay conditions.

\section{Determination of the protein content}

The protein content of the fractions obtained before and after ammonium sulfate fractionation was estimated by measuring the absorbance at $280 \mathrm{~nm}$.

\section{Effect of temperature on the enzyme activity and stability}

The effect of temperature on the activity of the partially purified enzyme was studied using skimmed milk as substrate. The substrate at a final concentration of
$10 \%$ skimmed milk in $0.01 \mathrm{M}$ calcium chloride, $\mathrm{pH} 6.5$, was pre-incubated at specified temperatures in a range of $30-90^{\circ} \mathrm{C}$ for $10 \mathrm{~min}$. Then the enzyme was added, and the reaction was proceeded at the same temperature until the discrete particles were discernible. The control tube was incubated without the enzyme at each temperature.

The thermal stability of the enzyme was tested by incubating the partially purified enzyme in 50 sodium acetate buffer, $\mathrm{pH} 5.0$, at different temperatures $\left(30-90^{\circ} \mathrm{C}\right.$ ) for $30 \mathrm{~min}$. Then, the remaining activity was measured at $37^{\circ} \mathrm{C}$ using $10 \%$ skimmed milk as substrate and expressed as percentage of the control.

\section{Storage stability}

Partially purified enzyme of moringa seeds was stored at 4 and $25^{\circ} \mathrm{C}$ for 7 days. The milk-clotting activity of the stored enzyme was assayed on every third day using skimmed milk as substrate as described above.

\section{Digestion of food protein}

Food protein digestion experiment was performed following the method described by Singh and Dubey (2011). Briefly, three cubical pieces of boiled egg albumen, $1 \mathrm{~g}$ each, were placed in $16 \mathrm{ml}$ test tubes. Then, $5 \mathrm{ml}$ of either moringa seed extract or rennet solution were added and the tubes were incubated at $37{ }^{\circ} \mathrm{C}$ for overnight. A control was used for comparison in which enzymes were replaced with distilled water.

\section{Statistical analysis}

Each determination was carried out and analyzed in triplicate and the figures were then averaged. The variation was assessed by the analysis of variance (ANOVA).

\section{RESULTS AND DISCUSSION}

Screening for milk-clotting activity from different parts of Moringa oleifera

Milk-clotting activity was screened from various parts (leaves, stems, flowers, unripe fruits, ripe fruits and seeds) of Moringa oleifera in order to use the part with the highest milk-clotting activity as a source of the enzyme. The results showed that the milk-clotting activity was only detected in the seeds extract and the other parts showed no activity for more than 5 hours incubation at $37^{\circ} \mathrm{C}$ (Table 1). However, when the reaction is continued for overnight at $37^{\circ} \mathrm{C}$ very mild curds were observed in all reaction mixtures. The overnight curds formation could be attributed to either the action of very weak and/or low concentration milk-clotting enzyme in these extracts or to the acidification effect of lactic acid that released during the fermentation of milk lactose by indigenous lactic acid bacteria. This has been supported by the findings of Pontual et al. (2012) who reported that moringa flower extract $(2,940 \mathrm{mg}$ of protein) was not able to hydrolyze azocasein, and it did not show milk-clotting activity using milk supplemented or not with $\mathrm{CaCl}_{2}$. High milk clotting activity in the moringa seeds extract was expected since most of the proteolytic enzymes in the plants are concentrated in the seeds where it degrade the storage protein during seed germination (Antao \& Malcata 2005). Similar to our findings, many previous works had been reported on the isolation of milk-clotting enzymes for the seeds of numerous plants (Elmazar et al., 2012; Egito et al., 2007; Mohamed Ahmed et al., 2009a,b; Naz et al., 2009; Nestor et al., 2012). However, various milkclotting enzymes has also been extracted from other parts of the plants (Anusha et al., 2014; Beka et al., 2014; Hashim et al., 2011; Guiama et al., 2010; Mazorra-Manzano et al., 2013; Pontual et al., 2012).

Table 1 Screening for milk clotting activity from various parts of Moringa oliefera

\begin{tabular}{lcccc}
\hline \multirow{2}{*}{$\begin{array}{l}\text { Moringa } \\
\text { parts }\end{array}$} & $\begin{array}{c}\text { Extraction solution } \\
\text { Distilled } \\
\text { Water (DW) }\end{array}$ & $\begin{array}{c}5 \% \mathrm{NaCl} \\
\text { in DW }\end{array}$ & $\begin{array}{c}\text { Sodium } \\
\text { acetate } \\
\text { buffer }\end{array}$ & $\begin{array}{c}5 \% \mathrm{NaCl} \text { in } \\
\text { Sodium acetate } \\
\text { buffer }\end{array}$ \\
\hline Leaves & nd & nd & nd & nd \\
Stems & nd & nd & nd & nd \\
Flowers & nd & nd & nd & nd \\
Ripe fruits & nd & nd & nd & nd \\
Un ripe fruits & nd & nd & nd & nd \\
Seeds & $19.62 \mathrm{U} / \mathrm{mL}$ & 230.84 & 220.01 & $3814.80 \mathrm{U} / \mathrm{mL}$ \\
\hline
\end{tabular}

Results are average of triplicate samples.

nd: not detected.

\section{Effect of different extractant on the milk-clotting activity}

In order to obtain the highest milk-clotting activity from moringa samples various extracting solution were tested. The results showed that moringa seeds extracted with $5 \% \mathrm{NaCl}$ in $50 \mathrm{mM}$ sodium acetate buffer, $\mathrm{pH} 5.0$, had higher milk-clotting 
activity compared to that extracted with the other extractants (Table.1, Fig. 1). Therefore, $5 \% \mathrm{NaCl}$ in sodium acetate buffer, $\mathrm{pH} 5.0$, was used as an extracting buffer throughout the study. This result is in a good agreement with the observation of Yousif et al. (1996) and Mohamed Ahmed et al. (2009a,b) who stated that water extract of Solanum dubium berries and seeds had less milkclotting activity compared to that extracted with $5 \% \mathrm{NaCl}$ in acetate buffer. Moreover, Guiama et al. (2010) obtained the maximum milk-clotting activity by soaking dried berries of nine Solanum species in $5 \% \mathrm{NaCl}$ solution. An increase in the ionic strength of the extracting solution apparently increases the solubility of the milk-clotting enzyme, and thus allows for increased extraction.

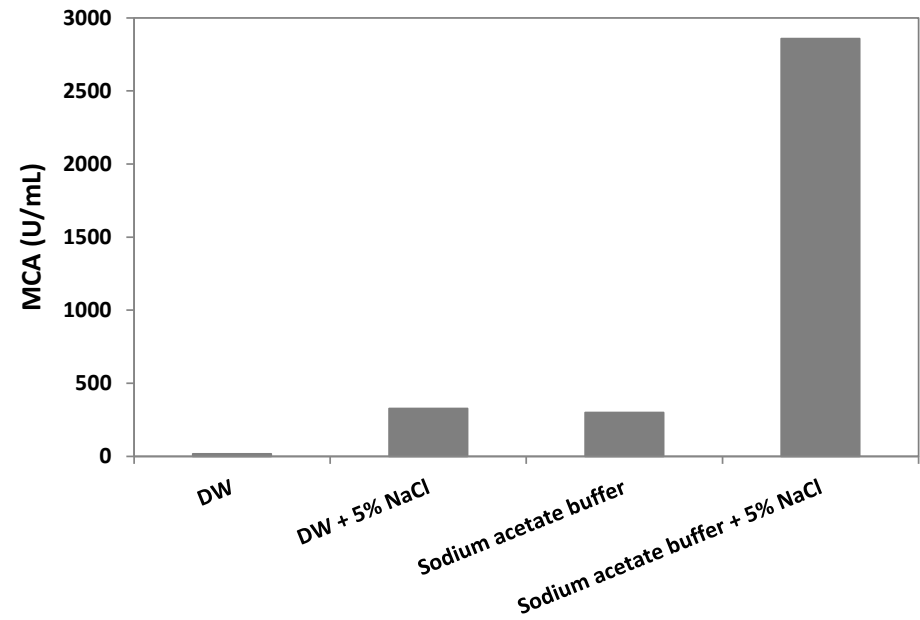

Figure 1 Ability of different extracting solutions to extract milk-clotting enzyme from the seeds of Moringa oleifera.

\section{Partial purification of the enzyme}

Ammonium sulfate precipitation was performed as a single purification step of milk-clotting enzyme from the seeds of Moringa oleifera. The crude extract (50 $\mathrm{ml}$ in $50 \mathrm{mM}$ sodium acetate buffer, $\mathrm{pH} 5.0$ ) was precipitated with $0-60 \%$ ammonium sulfate with $20 \%$ intervals as described in Material and Methods. The results showed that with increasing the ammonium sulfate concentration the milk clotting activity was gradually decreased $(P \leq 0.05)$ until completely vanished at $60 \%$ saturation (Fig. 2). Exceptionally, the highest milk-clotting activity was obtained with $20 \%$ ammonium sulfate saturation, which was 7 times higher compared to that of the crude extract. This result was comparable to those of Nestor et al. (2012) who reported that $20 \%$ ammonium sulfate gave the highest milk-clotting activity of Solanum elaeagnifolium seeds extract. Previously, a milk-clotting serine protease was partially purified from the seeds of Solanum dubium by using ammonium sulfate at saturation of $35-55 \%$ that lead to the salting out of more than $86 \%$ of the total protease in the crude extract (Mohamed Ahmed et al., 2009a). The application of ammonium sulfate at low saturation $(20 \%)$ in the current study is superior to high concentrations that usually used for the purification of milk-clotting enzymes from various sources (Mohamed Ahmed et al., 2009a; Pontual et al., 2012). The results obtained in the current study indicated that the degree of saturation of ammonium sulfate greatly affected the enzyme activity, yield and total protein as well as the enzyme purity. This procedure not only facilitates the effective removal of the brown colored materials in the crude seeds extract, but also concentrated the enzyme to a workable volume that could efficiently be used for milk coagulation in cheese making industry. Overall, a one-step and cheap purification procedure has been developed to partially purify milk-clotting enzyme from Moringa oleifera seeds. Such an economic purification procedure combined with the easy availability of the plant seeds makes large scale preparation of the enzyme is possible, allowing a broad study of its various aspects and hence probable applications.

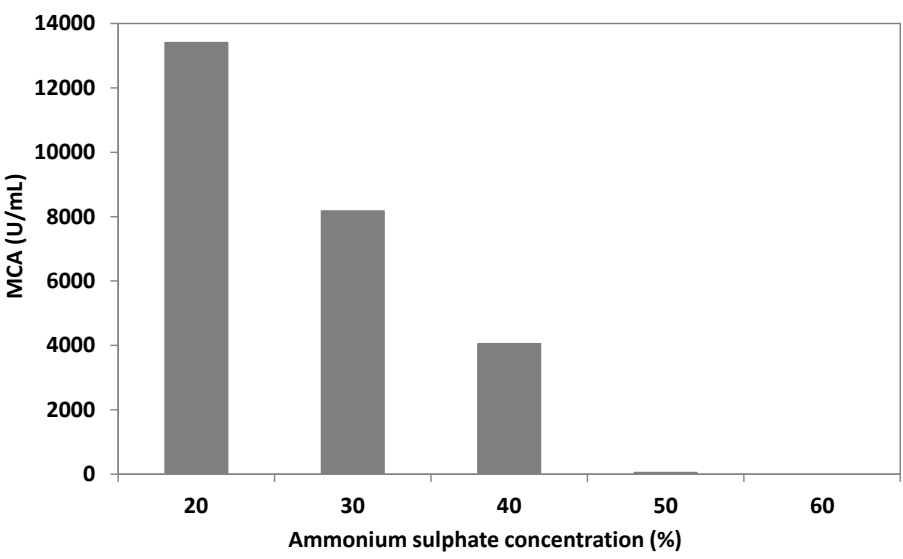

Figure 2 Ammonium sulfate fractionation of a milk-clotting enzyme from the seeds of Moringa oleifera.

\section{Milk-clotting and proteolytic activity of the enzyme}

The ratio of milk-clotting activity to proteolytic activity of the enzyme is a usefu indicator for its suitability as a rennet substitute for cheese making (Arima $\boldsymbol{e t}$ al., 1970). An enzyme with a higher ratio of milk-clotting to proteolyic activity is better able to form curd, obtain higher yield and with less bitterness development during cheese processing, while that with low ratio may developed lower curd recovery, weak curd firmness and the release of bitter peptides that affect the sensory properties of the final product (Mazorra-Manzano et al., 2013). Thus in the current study, the ratio of milk-clotting activity to proteolytic activity of the partially purified enzyme was evaluated and compared with those of some commercial milk coagulating enzymes (Table 2). Strikingly, partially purified enzyme from moringa seeds showed higher ratio of milk clotting activity to proteolytic activity compared to that of calf rennet, dubiumin and papain. The results obtained indicated that the partially purified enzyme of moringa seeds was highly active compared to calf rennet. This result is also supported by the coagulation behavior of the enzyme (Fig. 3a) which indicated that the partially purified enzyme greatly coagulated the skim milk compared to calf rennet and the control sample. Additionally, the partially purified enzyme from moringa seeds efficiently clotted the skimmed milk and formed a white and firm curd (Fig. 3b). It is well known that Chymosin, the main enzyme in commercial rennet's has a higher ratio of milk-clotting activity to protolytic activity than most coagulant substitutes from microbial and plants sources (Jacob et al., 2011). It has been previously reported that the ratio of milk-clotting activity/proteolytic activity of vegetable rennet was lower, resulting in cheese that was bitter during ripening time (Sousa et al., 2001). For example, papain, ficin, and bromelain have a higher proteolytic activity and produce a soft and bitter cheese. It is worth to note that in the current study the partially purified milk-clotting enzyme from moringa seeds demonstrated the highest ratio of milk-clotting to proteolytic activity among all milk clotting enzymes including calf rennet that is widely used in cheese making industry. The capability of the partially purified enzyme from moringa seeds to coagulate milk and form a firm curd combined with its high ratio of milk clotting to proteolytic activity could make it a useful renne substitute in the dairy industry. Though, more studies about quality of both milk curds and the cheese formed should be carried out in the future to confirm usefulness of this new and cheap coagulant in the dairy industry.

Table 2 Ratio of milk-clotting activity to proteolytic activity of Moringa oleifera seeds enzyme compared to that of other coagulants

\begin{tabular}{lccc}
\hline Enzyme & $\begin{array}{c}\text { Clotting Activity } \\
(\text { Unit/ml) }\end{array}$ & $\begin{array}{c}\text { Proteolytic Activity } \\
\text { (Unit/ ml) }\end{array}$ & Ratio \\
\hline M. oleifera seed & 13407.8 & 2.50 & 5279.0 \\
extract & 249.6 & 0.05 & 4992.0 \\
Rennet & 880.0 & 0.35 & 2490.0 \\
Dubiumin & 216.0 & 0.59 & 367.0 \\
papain & & & \\
\hline
\end{tabular}




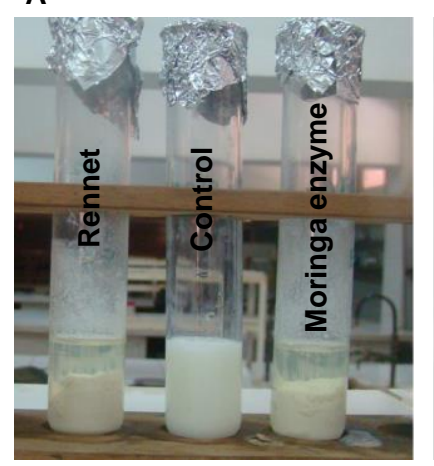

Figure 3 Milk-clotting properties of partially purified milk-clotting enzyme from the seeds of Moringa oleifera. Panel A: coagulation of skimmed milk by moringa seeds enzyme and commercial rennet. Panel B: cheese curd formed by the partially purified enzyme from moringa seeds.

\section{Effect of temperature on the enzyme activity and stability}

The temperature profile of the milk-clotting enzyme from plant extracts depends on several factors such as the plant source, tissue, concentration and type of protease (Mazorra-Manzano et al., 2013). The milk-clotting activity of the partially purified enzyme was examined using skim milk as a substrate at different temperatures ranging from 20 to $90^{\circ} \mathrm{C}$ for $30 \mathrm{~min}$. The results (Fig. 4) showed that the enzyme activity increased as the (reaction) temperature increased from 20 to $70^{\circ} \mathrm{C}$. The activity at $70^{\circ} \mathrm{C}$ was 10 -fold higher than that of the activity at $20^{\circ} \mathrm{C}$. The activity sharply decreased as the temperature of the reaction raised over $80^{\circ} \mathrm{C}$. However, at $80^{\circ} \mathrm{C}$ and $90^{\circ} \mathrm{C}$ the milk-clotting activity of the enzyme was still higher compared to that at temperatures below $60^{\circ} \mathrm{C}$. The effect of temperature on the catalytic activity of partially purified milk clotting enzyme of moringa seeds exhibited a typical activity-temperature relationship of enzymes. The increase of the milk-clotting activity at higher temperature could be attributed to the protein aggregation and molecular rearrangement in the protein structure (Najera et al., 2003). The conformational changes in the protein structure under high temperature could make it vulnerable to proteolysis because, protein unfolding can expose new cleavage sites to enzymatic hydrolysis. In agreement with our findings, high optimal temperature $\left(70^{\circ} \mathrm{C}\right)$ of milk-clotting enzymes from various plants has been reported (Mohamed Ahmed $\boldsymbol{e t}$ al., 2009a,b; Mazorra-Manzano et al., 2013; Pontual et al., 2012). Thermostability of the partially purified enzyme was examined by measuring the residual activity after incubating the enzyme at different temperatures. Since the enzyme had a high optimum temperature, its stability at temperature between 20 to $90{ }^{\circ} \mathrm{C}$ was studied. There was more than $80 \%$ retention of the milk-clotting activity of the enzyme after $1 \mathrm{~h}$ incubation at $50{ }^{\circ} \mathrm{C}$ (Fig. 4). However, the residual activity was quickly diminished when the enzyme was incubated for $1 \mathrm{~h}$ at $60^{\circ} \mathrm{C}$ or higher temperatures. With regards to the stability of the partially purified enzyme from moringa seeds at high temperature, it behaved like milk-clotting enzymes extracted from other vegetable and microbial sources. Thermal stability in the range of $30-60^{\circ} \mathrm{C}$ for milk clotting enzymes from different plant sources has been reported (Anusha et al., 2014; Nestor et al., 2012). However, the partially purified milk-clotting enzyme in the current study was characterized by its high thermal resistance as compared to calf rennet, since calf rennet reached its maximum activity at $45^{\circ} \mathrm{C}$, followed by a sharp decline when the temperature exceeded $50^{\circ} \mathrm{C}$ (Shehata et al., 1996). The storage stability of proteins and enzymes is usually a factor that limits their usefulness in many applications (Mohamed Ahmed et al., 2009b). The storage stability of the partially purified enzyme was determined by incubating the enzyme at either $4^{\circ} \mathrm{C}$ or $25^{\circ} \mathrm{C}$ for one week (Fig. 5). The results showed that the enzyme is quite sensitive to the storage temperature and retain about 50 and $30 \%$ of its milk-clotting activity when incubated for 1 week at $4{ }^{\circ} \mathrm{C}$ and $25^{\circ} \mathrm{C}$, respectively. The reduction of the enzyme activity during the storage could be attributed to the either the autolysis or the degradation by other contaminating proteolytic enzymes since the enzyme is not fully purified yet. Most of the isolated plant proteases studied undergo autodigestion at low protein concentrations such as procerain (Dubey \& Jagannadham 2003). However, some of the isolated milk-clotting plant serine proteases were found to resist autodigestion such as Religiosin B (Kumari et al., 2012) and dubiumin (Mohamed Ahmed et al., 2009b). The low storage stability of the partially purified enzyme from moringa seeds could be overcome by either complete purification or by the freeze drying of the enzyme. Complete purification will remove contaminating proteases while freeze drying will terminate autodigestion.

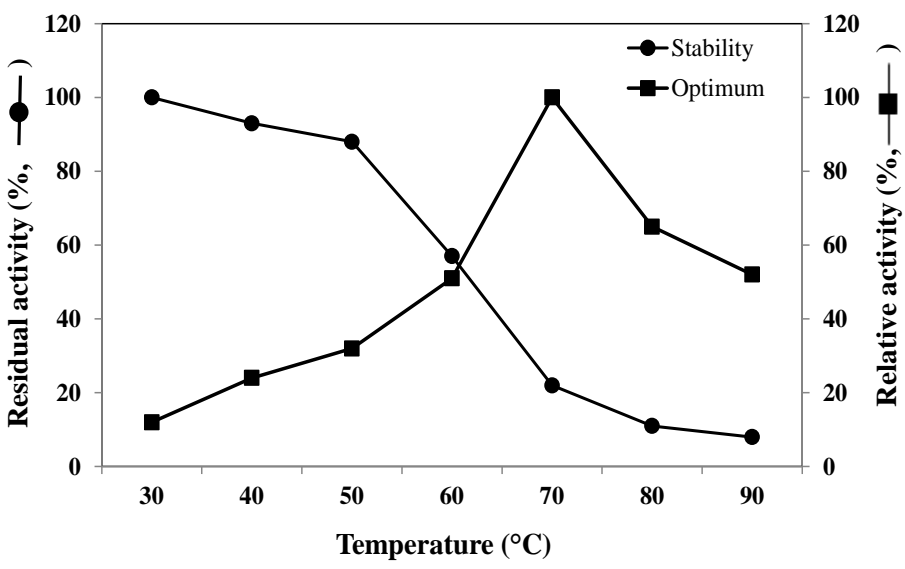

Figure 4 Effect of temperature on the activity and stability of partially purified milk-clotting enzyme from seeds of Moringa oleifera.

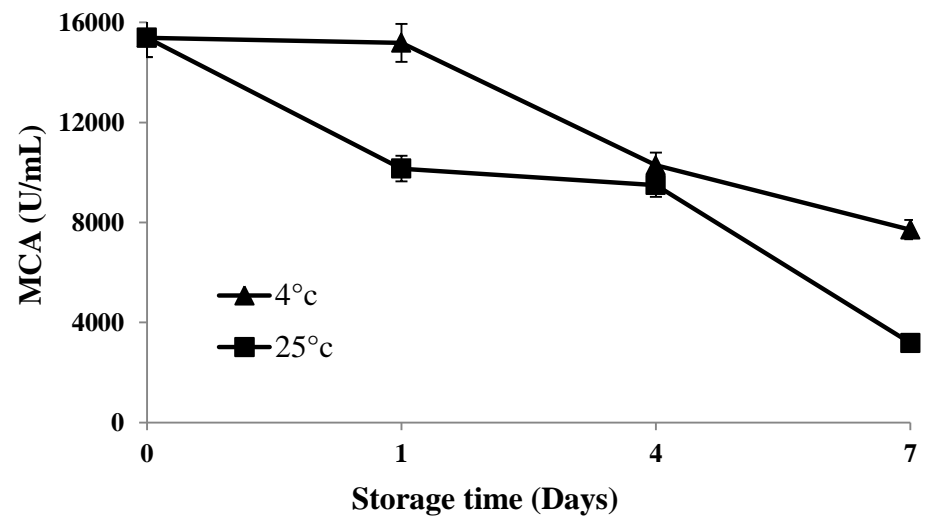

Figure 5 Storage stability of the partially purified milk-clotting enzyme from seeds of Moringa oleifera.

\section{Digestion of egg white protein}

Enzymatic hydrolysis of food proteins can release peptides able to exert different biological activities. Egg white proteins are used extensively in food systems due to their unique functional (foaming, gelling, emulsifying) and nutritional properties (Mine \& Zhang 2013). In order to assess the digestive ability of the partially purified enzyme from moringa seeds on food proteins others than those of milk, the enzyme was incubated with egg white proteins for $24 \mathrm{~h}$ at $37^{\circ} \mathrm{C}$ Commercial calf rennet and distilled water were used as positive and negative controls, respectively. Unexpectedly, the results showed that the partially purified enzyme of moringa seeds was incapable to digest egg white proteins, whereas, the commercial calf rennet digested egg white protein at lower rate (Fig. 6). The digestibility of egg white proteins by both enzymes (moringa seeds enzyme and calf rennet) was not visible in the test tubes incubated for $24 \mathrm{~h}$. However, when removing the cubes of egg white proteins from the test tubes, the protein cubes that treated with calf rennet was fragile with many creaks and wholes, whereas, those incubated with either the partially purified enzyme or distilled water were still compact with no changes. Contradictory to this results, a milk-clotting cysteine protease from Calotropis procera (Procerain B) was found to digest cubes of egg white proteins and reducing their weight from 500 to $195.5 \mathrm{mg}$ (Singh \& Dubey 2011). The results of the current study indicated the inability of the partially purified enzyme from moringa seeds to digest egg white proteins. Although this phenomena narrowed the application of the new enzyme in food industry, it is however, increased the suitability of the enzyme to be used in cheese making as a new and specific rennet substitute. The specificity of this enzyme toward milk proteins was supported by its high ratio of milk-clotting to proteolytic activity (Table 2). The specificity of milk-clotting enzyme toward milk caseins and especially k-casein is a great determinant of the enzyme to be used in cheese making. 


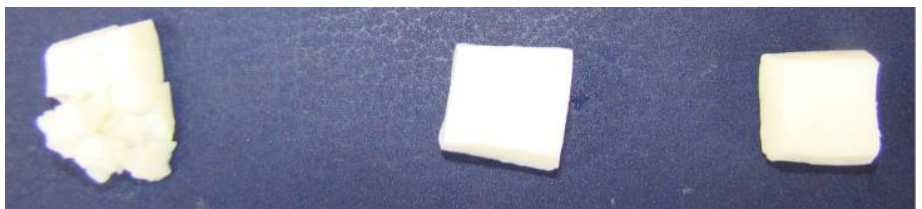

Rennet Blank
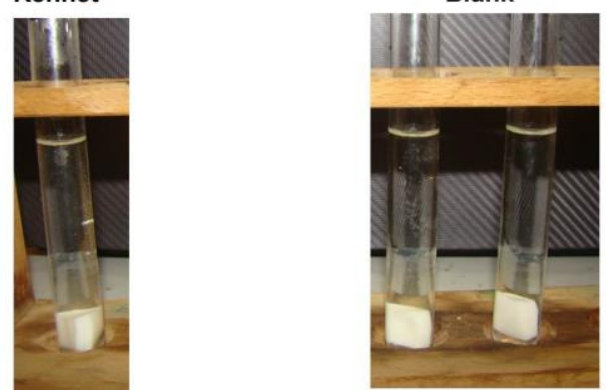

Moringa seed extract

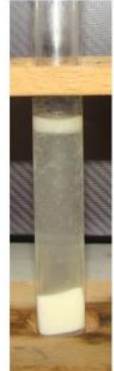

Figure 6 Digestion of egg white protein by partially purified milk-clotting enzyme from seeds of Moringa oleifera in comparison with calf rennet and the blank (with no enzyme).

\section{CONCLUSION}

To the best of our knowledge, this is the first report the partial purification of a milk-clotting enzyme from the seeds of Moringa oleifera. The simple and cheap procedure for partial purification of the enzyme applied in the current study, combined with the availability of the plant seeds, could possibly be used for large-scale production of the enzyme, allowing a broad study of its various aspects and hence probable applications. Moreover, the high specificity in terms of its high ratio of milk-clotting to proteolytic activity could pave the way for its uses in the cheese industry as alternative to calf rennet. Additional studies on the complete purification and characterization of this promising enzymes together with the intense evaluation of the quality of cheese curd produced by its action will shed more light into its commercial suitability.

Acknowledgments: Authors are thankful to the engineer Salah Abdoun the head of Moringa Research and Development Group Farms for providing moringa samples and his fruitful discussion.

\section{REFERENCES}

ANTAO, C.M. \& MALCATA, F. X. 2005. Plant serine proteases: biochemical, physiological and molecular features. Plant Physiology and Biochemistry, 43, 637-650. http://dx.doi.org/10.1016/i.plaphy.2005.05.001

ANUSHA, R., SINGH, M. K. \& BINDHU O.S. 2014. Characterization of potential milk coagulants from Calotropis gigantean plant parts and their hydrolytic pattern of bovine casein. European Food Research and Technology, 238, 997-1006. http://dx.doi.org/10.1007/s00217-014-2177-0

ARIMA, K., YA, J. \& IWASAKI, S. 1970. Milk-clotting enzyme from Muco pusillus var. Lindt. In: Methods in enzymology, (eds. Pearlman, E. G., and Lorand, L.). Academic Press, New York, pp. 446-459. ISBN: 978-0-12 181881-4

BEKA, R.G., KRIER, F., BOTQUIN, M., GUIAMA, V.D., DONN, P., LIBOUGA, D.G., MBOFUNG, C.M., DIMITROV, K., SLOMIANNY, M.-C., GUILLOCHON, D. \& VERCAIGNE-MARKO, D. 2014. Characterisation of a milk-clotting extract from Balanites aegyptiaca fruit pulp. International Dairy Journal, 34, 25-31. http://dx.doi.org/10.1016/i.idairyj.2013.06.013

DUBEY, K.V. \& JAGANNADHAM, V.M., 2003. Procerain, a stable cysteine protease from the latex of Calotropis procera. Phytochemistry, 62, 1057-1071. http://dx.doi.org/10.1016/S0031-9422(02)00676-3

EGITO A.S., GIRARDET, J.-M., LAGUNA, L. E., POIRSON, C., MOLLE, D. MICLO, L., HUMBERT, G. \& GAILLARD, J. -L. 2006. Milk-clotting activity of enzyme extracts from sunflower and albizia seeds and specific hydrolysis of bovine k- casein. International Dairy Journal, 17, 816-825. http://dx.doi.org/10.1016/j.idairyj.2006.09.012

ELMAZAR M. M. E., EL-SAYED S. T. \& AL-AZZOUNY R. A. 2012 Screening Some Local Egyptian Seeds Extract for Milk-Clotting Activity and Physicochemical Characterization of Brassica Napus Seed Extract. Journal of Agriculture and Food Technology, 2(2), 28-34.

Fahey, J. W. 2005. Moringa oleifera: A Review of the Medical Evidence for Its Nutritional, Therapeutic, and Prophylactic Properties. Part 1. Trees for Life.

FOX, P.F. \& MCSWEENEY, P. L. H. 2004. Cheese: An Overview in Cheese: Chemistry, Physics and Microbiology, 3rd Edn. Chapman and Hall London. ISBN: 0-1226-3651-1

GUIAMA V. D., LIBOUGA D. G., NGAH E. \& MBOFUNG C. M. 2010. Milkclotting activity of berries extracts from nine Solanum plants. African Journal of Biotechnology, 9(25), 3911-3918.
HASHIM M. M., MINGSHENG D., IQBAL M. F. \& XIAOHONG C. 2011 Ginger rhizome as a potential source of milk coagulating cysteine protease. Phytochemistry, 72, 458-464. http://dx.doi.org/10.1016/j.phytochem.2010.12.002 JACOB, M., JAROS, D. \& ROHM, H. 2011. Recent advances in milk clotting enzymes. International Journal of Dairy Technology, 64(1), 14-33. http://dx.doi.org/10.1111/j.1471-0307.2010.00633.x

KUMARI, M., SHARMA, A. \& JAGANNADHAM, M. V. 2012. Religiosin B, a milk-clotting serine protease from Ficus religiosa. Food Chemistry, 131, 12951303. http://dx.doi.org/10.1016/j.foodchem.2011.09.122

MACEDO, I. Q., FARO, C. J. \& PIRES, E. M. 1996. Caseinolytic Specificity of Cardosin, an Aspartic Protease from the Cardoon Cynara cardunculus L.: Action on Bovine $\beta$ - and $\alpha$-Casein and Comparison with Chymosin. Journal of Agricultural and Food Chemistry, 44, 42-47. http://dx.doi.org/10.1021/jf9406929 MAZORRA-MANZANO, M. A., PEREA-GUTIÉRREZ, T. C., LUGOSÁNCHEZ, M. E., RAMIREZ-SUAREZ, J. C., TORRES-LLANEZ, M. J., GONZÁLEZ-CÓRDOVA, A. F. \& VALLEJO-CORDOBA， B. 2013. Comparison of the milk-clotting properties of three plant extracts. Food Chemistry, 141, 1902-1907. http://dx.doi.org/10.1016/j.foodchem.2013.05.042 MINE, Y. \& ZHANG, H. 2012. Egg components in food systems. Biochemistry of Foods (3rd ed.), Academic Press, San Diego, pp. 215-241. ISBN: 978-0-12242352-9

MOHAMED AHMED, I. A., MORISHIMA, I., BABIKER, E. E. \& MORI, N 2009a. Characterization of partially purified milk-clotting enzyme from Solanum dubium Fresen seeds. Food Chemistry, $116 \quad$ (2), 395-400. http://dx.doi.org/10.1016/i.foodchem.2008.11.072

MOHAMED AHMED, I. A., MORISHIMA, I., BABIKER, E. E. \& MORI, N. 2009b. Dubiumin, a chymotrypsin-like serine protease from the seeds of Solanum $\begin{array}{lllll}\text { dubium Fresen. } & \text { Phytochemistry, } 70 & \text { (4), } & \text { 483-491. }\end{array}$ http://dx.doi.org/10.1016/j.phytochem.2009.01.016

MOHAMED AHMED, I.A., BABIKER, E.E. \& MORI N. 2010. pH stability and influence of salts on activity of a milk-clotting enzyme from Solanum dubium seeds and its enzymatic action on bovine caseins. LWT of Food Science and Technology, 43, 759-764. http://dx.doi.org/10.1016/j.lwt.2009.12.011

NAJERA, A. I., DE RENOBALES, M. \& BARRON, L. J. R. 2003. Effects of $\mathrm{pH}$, temperature, $\mathrm{CaCl}_{2}$ and enzyme concentrations on the rennet-clotting properties of milk: a multifactorial study. Food Chemistry, 80, 345-352. http://dx.doi.org/10.1016/S0308-8146(02)00270-4

NAZ, S., MASUD, T. \& NAWAZ, M. A. 2009. Characterization of milk coagulating properties from the extract of Whithania coagulans. International Journal of Dairy Technology, 62, 315-320. http://dx.doi.org/10.1111/j.14710307.2009.00492.x

NESTOR, G.-M., RUBI, C.-G. D. \& HECTOR, J.-C. 2012. Exploring the MilkClotting Properties of a Plant Coagulant from the Berries of S. elaeagnifolium var. Cavanilles. Journal of Food Science, 71(1), C89-C94. http://dx.doi.org/10.1111/j.1750-3841.2011.02468.x

PONTUAL, E.V., CARVALHO, B.E.A., BEZERRA, R.S., COELHO, L.C.B.B., NAPOLEÃO, T.H. \& PAIVA, P.M.G., 2012. Caseinolytic and milk-clotting activities from Moringa oleifera flowers. Food Chemistry, 135, 1848-1854. http://dx.doi.org/10.1016/j.foodchem.2012.06.087

ROSEIRO, L. B., BARBOSA, M. M., AMES, J. \& WILBEY, R., 2003. Cheese making with vegetable coagulants; the use of Cynara cardunculus L.for the production of ovine milk cheeses. International Journal of Dairy Technology, 56 , 76 - 85. http://dx.doi.org/10.1046/j.1471-0307.2003.00080.x

SARATH, G., MOTTE, R. S. \& WANGER, F. M. 1989. Protease assay methods. In: Beynon, R. J., Bond, J. S. (Eds), Proteolytic enzyme- A practical approach. IRL Press, Oxford, Pp. 25-55. ISBN: 0-19-963058-5

SHEHATA, A.E., FAYET, E. A., ISAMIL, A. A. \& SALEM, M. M. 1996 Production and characterization of bacterial coagulants as calf rennet replace for Egyptian cheese making. Egyptian Journal of Food Science, 24 (3), 417-449.

SIDRACH, L., GARCIA-CANOVAS, F., TUDELA J. \& RODRIGUEZ-LOPEZ, J. N. 2005. Purification of cynarases from artichoke (Cynara scolymus L.) enzymatic properties of cynarase A. Phytochemistry, 66, 41-49. http://dx.doi.org/10.1016/j.phytochem.2004.10.005

SINGH, A. N. \& DUBEY, V. K. 2011. Exploring application of Procerain B, a novel protease from Calotropis procera, and characterization by $\mathrm{N}$-terminal sequencing as well as peptide mass fingerprinting. Applied Biochemistry and Biotechnology, 164, 573-580. http://dx.doi.org/10.1007/s12010-011-9158-6

SOUSA, M. J., ARD, Y. \& MCSWEENEY, P. L. H. 2001. Advances in the study of proteolysis during cheese ripening. International Dairy Journal, 11, 327-345. http://dx.doi.org/10.1016/S0958-6946(01)00062-0

VERISSIMO, P., ESTEVES, C., FARO, C. \& PIRES, E. 1995. The vegetable rennet of Cynara cardunculus L. contains two proteinases with chymosin and pepsin-like specificities. Biotechnology Letters, 17, 614-645. http://dx.doi.org/10.1007/BF00129389

YOUSIF, B. H., MCMAHON, J. D. \& SHAMMET, M. K., 1996. Milk-clotting Enzyme from Solanum dobium Plant. International Dairy Journal, 6, 637-644 http://dx.doi.org/10.1016/0958-6946(95)00025-9 